\title{
WHEN CONVERSION IS JOY \\ AND DEATH VICTORY:

\author{
HISTORICAL FOUNDATIONS \\ OF THE DOCTRINE OF PERSEVERANCE
}

Ján Henžel

\begin{abstract}
Summary
Once people become converted one of their major existential concerns will be whether and how will they persevere in their right standing with God. As this concern is as old as Christianity, it is illuminating to see the historical developments of the doctrine of perseverance. Foundations of the doctrine may be found in the writings of Aurelius Augustine. There are to be found the four distinguishing approaches to the doctrine of perseverance developed in the course of history: (1) perseverance is necessary for believers' salvation and that it is a gift of God but they are uncertain whether this gift was given to them; (2) perseverance is necessary, God determines who perseveres and the believer may be certain of this gift; (3) perseverance is a necessary gift but God does not determine who perseveres and the believer is uncertain of his final state; (4) perseverance is necessary for obtaining final rewards but not for believers' salvation.
\end{abstract}

We shall start our journey in the post-biblical period. One has to remember that despite the historical continuity with the New Testament the Apostolic Fathers stepped into a different world regarding soteriology. Not that the idea of salvation was foreign in the GraecoRoman world, but it was quite different from the Jewish mindset of biblical writers. The first centuries of Christianity literally proved Jesus' prediction to his followers: 'In this world you will have trouble. But take heart! I have overcome the world' (Jn. 16:33). They did have trouble, but the blood of martyrs became the seed of the Church. However, not all Christians were victorious under the pressure of 
persecution and other temptations. Thus very early the Apostolic Fathers had to deal with issues of post-baptismal sin and second repentance.

\section{Salvation is Based on God's Grace}

After the vision of the Emperor Constantine I in 312, when the alliance of throne and altar started to cement, the spread of Christianity began to have completely different reasons. In this decisive transitional period, the most influential thinker was Aurelius Augustine. His theological reflection has left a permanent mark on Christian theology of subsequent generations and also on the doctrine of the perseverance of the saints.

Famous is Augustine's controversy with Pelagius and his followers. Augustine, in the second book of De peccatorum meritis remissione, continuously discusses the question why people sin and why some people turn toward God. It is decided that it happens by divine election. There is a development in Augustine's thought on this matter. In his unfinished exposition of Romans he says, along with Ambrosius: 'Election is a choice which God makes among men, and since it would be unjust if he arbitrarily gave preference to some, the choice must be based upon some difference... and that difference is one of "merit".'1 God offers grace freely to all men, but they themselves have to receive it by faith. Then they get the aid of the Holy Spirit. Even then they will inherit eternal life only if they remain in the Spirit. ${ }^{2}$ Reading Romans 9 he is persuaded that election to grace comes prior to any decision on man's part. Whether a man believes or does not is decided by God. But he warns: 'Only let no one so dare to destroy the decision of the will as to wish to excuse sin.' ${ }^{3}$ Here is Augustine's Herculean task; to uphold the existence of free choice as the source of evil and to defend the need for grace in the doing of saving actions, while maintaining that grace did not eliminate the need for the will to adhere to God.

Augustine explains the relationship between the grace of God and the will of man by his theory of volition which he consistently holds throughout his writings. According to this theory the willing belongs to

\footnotetext{
Exp. ad Rom., q. 68.

Exp. ad Rom., q. 60.

Quoted by C. Kirwan, Augustine (London: Routledge, 1989), 82.
} 
men, but men cannot will anything unless something attracts themunless something occurs to them. ${ }^{4}$

Is God not unjust to those who are not chosen? God is just to them because he is justly abandoning them to their sin and its consequences, but God is merciful to the chosen ones whom he rescues. It is important to notice, especially in the light of later scholasticism, that the explanation of the final product, the saved or damned man, indicates the nature of divine decree and not vice versa. The divine decree of election only explains that God's mercy was given to some. "[T]he grace of God, both of the beginning [of faith] and of perseverance to the end, is not given according to our merits, but according to his most secret, and at the same time most just, wise, and benevolent will... ${ }^{5}$ In the same work Augustine stresses that 'the possibility of having faith, like the possibility of having charity, belongs to the nature of man, but actually to have faith, as actually to have charity, belongs to the grace of the faithful. ${ }^{6}$ Every man has a potential for faith and love, but only those chosen by God have actual faith and actual love. Here however is a tension Augustine never sufficiently resolved.

At the end of his life Augustine comments: 'In the solution of this question, I, indeed, labored in defence of the free choice of the human will; but the grace of God conquered. ${ }^{7}$ So much did it conquer that he thought that even the good works which the justified do, and by which they merit eternal life, are gifts of God, and not the result of human free choice. Everything is by grace. However, when establishing his theology of predestination Augustine is aware of two problems - one of the beginning of faith, which is based upon prevenient grace, prior to man's decision, and another of perseverance in the faith, which is based upon subsequent and co-operating grace.

This led the monks of Hadrumetum and of Marseilles to question whether predestination makes rules, exhortations and prayer superfluous or meaningless. To prove that it does not, Augustine affirms: "[W]ho dares to say that at any time the Church has not prayed, or not prayed sincerely, either that unbelievers might believe or that believers might persevere. But if it has always prayed for these

\footnotetext{
De lib. arb., III, 21-35.

De don. pers., 13.33.

De praed. sanct., 5.10 .

Retr., 2.27.
} 
benefits, it has indeed always believed that they were gifts of God.' ${ }^{8}$ If seen in the historical context, Augustine wrote these words being aware of the advancing barbarian forces from the north-west on the one hand and of the still sheltered environment of the monasteries of Hadrumetum and Marseilles for whom the doctrine of predestination may have been a stumbling-block; but for the ageing Augustine aware of the looming threat it was a doctrine of survival.

While writing his City of God, Augustine had to refute the errors that those who "have received the baptism of Christ, and eaten the body of Christ, in the body of Christ ... shall not die eternally, but at one time or other obtain eternal life; and all that wickedness of theirs shall not avail to make their punishment eternal, but only proportionately long and severe' ${ }^{9}$ and that 'all catholics who continue in the faith, even though by the depravity of their lives they have merited hell fire, shall be saved on account of the "foundation" of their faith." ${ }^{10}$ This foundation is Jesus Christ and so they interpret 1 Corinthians 3:11-15 in the sense that although one is building upon this foundation wood, hay, stubble, he shall be saved by fire. Augustine is refuting these errors in 21.25 and 21.26 interestingly not by referring to predestination but by putting the opponents' arguments from Scripture into harmony with the overall teaching of the Bible. ${ }^{11}$ That was one of Augustine's ways of denouncing the principle of 'once saved, always saved'.

The other reason lies within his definition of perseverance. When Augustine speaks about perseverance, he means the gift of God by which the elect persevere in Christ to the end. 'Thus, it is uncertain whether anyone has received this gift so long as he is still living.' 12 Augustine does not believe that the Christian can know with certainty that he is among the elect and therefore that he will persevere. 'Consequently, people should not say that perseverance is given to anyone to the end, save when the end itself has come, and the person to whom it has been given has been found to have persevered to the end. ${ }^{13}$

8 De don. pers., 23.65.

9 De civ. Dei, 21.20.

10 De civ. Dei, 21.21.

11 De civ. Dei, 21.25. and 21.26.

12 De don. pers., 1.1.

13 De don. pers., 6.10. 
Because man's will is unstable despite the co-operating grace, Augustine cannot give much present assurance of final perseverance. Nevertheless "if grace is with us, then there is no possibility that we shall "fall out" of love as easily as we "fell into" it. Through Christ we have received the "more powerful" grace which will enable us to persevere to the end. 14

Perseverance understood in Augustine's terms is a gift that cannot be lost. However, this gift was given not just to be enjoyed but to enable us to walk the hard way of Christ. 'But perseverance to the end, because no one has it except a person who perseveres to the end, many can have, but no one can lose. ${ }^{15}$ In the next question however he explains that there is a sense in which even final perseverance can be lost 'through some obstinacy'. But if that happens, then perseverance has been a gift that was hoped to be possessed, and therefore it can be lost. Here too he safeguards the assurance of the believers by pointing to their duty to pray, 'Bring us not into temptation'. 'Therefore, whoever asks this and is favourably heard, is not brought into the temptation of obstinacy, by which he becomes capable or deserving of the loss of his perseverance in sanctity. ${ }^{16}$ Christians by trusting in the faithfulness of God are in contact with that power that leads to salvation.

Augustine goes to great lengths to stress the importance of prayer for perseverance. Perseverance in the faith is given only to those who seek it. 'God has prepared some things to be given even to those who do not pray for them, such as the beginning of faith, but other things to be given only to those who pray for them, such as perseverance to the end. ${ }^{17}$ Because perseverance is a gift of the grace that co-operates with man, it is very important to Augustine that it should be not only prayed for but also preached and especially to those who are within the Church, so that 'he who hears these things with obedience should glory, not in man, and consequently not in himself, but in the Lord. ${ }^{18}$

In our survey of Augustine's doctrine of grace and predestination, we have seen that both the beginning as well as the completion of salvation depend on God's grace. All the following Western Christian

\footnotetext{
14 De corr. et gr., 11.31-32.

15 De don. pers., 6.10.

16 De don. pers., 6.11.

17 De don. pers., 16.39.

18 De don. pers., 24.66.
} 
thinkers have more or less attempted to base their understanding of the doctrine of perseverance on ideas of Augustine or of those he reacted to. We have arranged them into four groups:

1. Those who maintain that perseverance is necessary for believers' salvation and that it is a gift of God but they are uncertain whether this gift was given to them.

2. Those who believe that perseverance is necessary, God determines who perseveres and the believer may be certain of this gift.

3. Those who believe that perseverance is a necessary gift but God does not determine who perseveres and the believer is uncertain of his final state.

4. Those who maintain that perseverance is necessary for obtaining final rewards but not for their salvation.

\section{Perseverance Is a Necessary Gift of God but Believers Cannot Be Certain It Was Given to Them}

Thomas Aquinas deals with the question of why some people are saved and others are not in Question 23 of his Summa Theologica.

Now when a thing cannot reach an end by its own natural power, then it has to be lifted up and sent there by another, as when an archer flights an arrow to the target. So a creature of intelligence, capable of eternal life, is brought there, properly speaking, as sent by God... Accordingly the planned sending of a rational creature to the end which is eternal life is termed predestination, for to predestine is to send. And so it is clear that predestination as regards what it does objectively is a part of Providence. ${ }^{19}$

Since predestination is part of God's providence, man's destination to eternal life is absolutely certain with God but not at all to the man himself. Predestination does not cause its effect out of necessity. ${ }^{20}$

Aquinas built his doctrine of perseverance upon the thought of Augustine and tried to integrate it with his own philosophical understanding of the freedom of the human will and with Aristotle's Ethics. He distinguishes three senses of the term 'perseverance': (1) 'the habit of mind by which a man stands firm', (2) 'habit by which a man holds the purpose of persevering in the good to the very end' and (3) 'continuance in good to the very end of life'. ${ }^{21}$ Only this third

19 Thomas Aquinas, Summa Theologiae, vol. 5 (Oxford: Blackfriars, 1967), Ia. Q. 23., Art. 1 .

20 Aquinas, Summa, Ia. Q. 23., Art. 6c.

21 Aquinas, Summa, vol. 30, IIa, Q. 109, Art. 10. Here we must remember that in the context of medieval Scholastics 'habit' is 'a perfection added to the soul which 
sense is strictly theological. According to Aquinas for perseverance in the first two senses the man does not need any special grace. He just has to persevere. However in the third sense of perseverance 'after someone has been justified by grace, he needs to ask God for this gift of perseverance, so as to be kept from evil to the very end of life. For grace is given to many to whom it is not given to persevere in grace. ${ }^{22}$ So perseverance has both a 'historical' and an 'eschatological' dimension as it is concerned with the course and the culmination of life.

Because Aquinas is more concerned with the ethical than with the purely theological aspects of perseverance he places more emphasis on human will than does Augustine. 'Man can fall into sin on his own but he cannot emerge from it alone without the help of grace.' So even if he does good it 'does not make him persevere in this, because of himself he is liable to sin, and so he needs the help of grace to persevere in good. ${ }^{23}$ Free will is changeable by definition, therefore even the will restored by grace needs God's assistance to keep itself in good. Good intentions do not necessarily produce good results.

In question 138 Aquinas recognises two vices opposed to perseverance: 'soft living' and 'obstinacy'. While the soft type holds on less than he should, the obstinate 'sticks to his own idea until victory'; whereas 'the man who perseveres holds to his own view precisely as he should'. ${ }^{24}$ Thus the Christian is required to continue in operative grace until the end; but he has no way of knowing whether he really does and even less whether he finally will.

Major parts of Aquinas' teaching were codified by the Council of Trent. It can be said, with a little oversimplification, that it was the Roman Catholic answer to the Reformation. Nowhere is Aquinas' influence more apparent than in its fifth and sixth sessions concerning original sin and justification, which is the longest and most elaborate of all the decrees. H. Jedin evaluates the decree on justification as being

the Church's authoritative answer to the teaching of Luther and the Confessio Augustana on grace and justification. The reformed doctrines of Zwingli and Calvin were only lightly touched upon in the course of the debate. The Catholic doctrine of justification as defined by the Council was on the one hand as far

disposes the person to good acts that are originated to the supernatural good that is God.' See J. Wawrykow, 'Thomas Aquinas', in Fitzgerald (ed.), Augustine, 830.

22 Summa, vol. 30, IIa, Q. 109, Art. 10.

23 Summa, vol. 30, IIb, Q. 137, Art. 4.

24 Summa, vol. 42, IIb, Q. 138, Art. 2. 
removed from Pelagianism, which excludes the supernatural action of God's grace from the process of salvation, as it was on the other from the Protestant doctrine in which man's co-operation vanishes (Rivière). ${ }^{25}$

In Chapter 1 of the Decree Concerning Justification building upon the previous Decree Concerning Original Sin, the Council Fathers stated that neither the Gentiles nor the Jews were able to liberate themselves from sin and the power of the devil and death. The question of how they are then justified is answered in chapter 3, through Christ who 'died for all, yet not all receive the benefit of his death, but only those to whom the merit of his passion is imparted; ... so, if not reborn in Christ, they would never be justified.' ${ }^{26}$ The justification is further described as translatio from the state of the first Adam, 'to the state of grace and of adoption children of God through the agency of the second Adam'. ${ }^{27}$

The process of justification proceeds 'from the predisposing grace of God' without any merits on the part of sinners who are called. ${ }^{28}$ But already at this early stage in co-operating grace the Council Fathers shift the emphasis more towards the participation of the sinner than was the case with Augustine. The more participation from the sinner is demanded the less assurance of his final state he gets. A. Stakemeier also recognises that the principal difference between the teaching of the Council and Luther is the inclusion of the human will into the process of justification and indeed the whole process of salvation. ${ }^{29}$ Sinners through God's helping grace 'convert themselves to their own justification by freely assenting to and co-operating with that grace. ${ }^{30}$ Sinners have much space for their own actions at every stage in the process of justification. They understand themselves to be sinners, turn themselves 'to thoughts of God's mercy; they rise to hope', 'they begin to love him' and 'they are proposing to receive baptism ...' ${ }^{31}$

25 H. Jedin, A History of the Council of Trent, 2 vols. (St. Louis: B. Herder Book Co. , 1961), 2.307.

26 Session 6, Decree on Justification, ch. 1, in N.P. Tanner \& G. Alberigo (eds.), Decrees of the Ecumenical Councils, 2 vols. (London: Sheed \& Ward, 1990), 671. Further references are to the Decree on justification given in chapter numbers.

27 Ch. 4.

28 Ch. 5.

29 A. Stakemeier, Das Konzil von Trient über die Heilsgewißheit (Heidelberg: F.H. Kerle, 1947), 175.

30 Stakemeier, Das Konzil, 175.

31 Ch. 6. 
It is important to note that the Council understands by justification 'not only the forgiveness of sins but also the sanctification and renewal of the inward being by a willing acceptance of the grace and gifts whereby someone from being unjust becomes just.' ${ }^{32}$ In this way 'justification itself becomes not only transformationist but a process. Justification is here not forensic or declarative, but distributive. ${ }^{33}$ Modern Catholicism reflected in the Catechism of the Catholic Church has avoided the categories of causes but its substance of justification remains the same. ${ }^{34}$

Both Protestant and Catholic schools agree, 'that no devout person ought to doubt the mercy of God, the merit of Christ and the power and efficacy of the sacraments. ${ }^{35}$ On the other hand through fear of the spiritual complacency to which the Reformers' teaching of assurance might lead, the Council strongly denies the personal confidence of a Christian. ' $(\mathrm{N}) \mathrm{o}$ one can know, by that assurance of faith which excludes all falsehood, that he has obtained the grace of God. ${ }^{36}$ The reason is not that God might 'abandon those once justified by his grace, unless he is first deserted by them. ${ }^{\prime 37}$ Thus justification received should increase by observance of the commandments and 'faith co-operating with good works', but it can also be lost. Chapter 16 states that to those who persevere to the end 'eternal life should be held out, both as a grace promised in his mercy through Jesus Christ to the children of God, and as a reward promised by God himself, to be faithfully bestowed, on the promise of God himself, for their good works and merits. ${ }^{38}$ But confidence in one's own perseverance is a presumption: 'let no one promise himself with an absolute certainty any definite outcome'. Christians can only know 'that they are reborn to the hope of glory, and not yet to glory itself, they ought to tremble about the struggle ... which still remains and in which they cannot be victors unless, with the grace of God ...'39

32 Ch. 7.

33 D.A. Carson, 'Reflections on Salvation and Justification in the New Testament' in Journal of the Evangelical Theological Society 40 (1997) 600.

34 Catechism of the Catholic Church (London: Geoffrey Chapman, 1995). See $\S \S 1987-2005$.

35 Ch. 9.

36 Ch. 9.

37 Ch. 11.

38 Ch. 16.

39 Ch. 13 
This is the ground for the strong wording of Canon 16 of the same Decree: 'If anyone says with absolute and infallible certitude (unless he shall have learned this by a special revelation) that he will certainly have that great gift of final perseverance: let him be anathema.' ${ }^{40}$ Canon 22 denies that one can persevere without the special help of God. Canon 26 assures that the just may for the good works done in God expect and hope for an eternal reward from God through His mercy and the merit of Jesus Christ, if by doing well and by keeping the divine commandments they persevere to the end. ${ }^{41}$ The Council distinguishes here between posse perseverare and perseverantia actualis. The latter is not an automatic result of the former.

Stakemeier concludes his theological evaluation of chapter 13: 'That we can have no absolute certainty of the donum perseverantiae is based not on the randomness of God's will; it comes from our own weakness and human fragility. That's why it was not the Council's intention to eliminate the pleasant assurance of Christian's salvation. ${ }^{42}$ Jedin however is not so positive, since his approach to the Decrees is that they are just theological explanations for the Canons.

The Council's aim was to draw a line of demarcation between Catholic dogma and belief and Protestant teaching. This delimitating function of the decree was realised, in the first instance, by means of thirty-three canons which are no mere appendage of the doctrinal chapters. As a matter of fact the doctrinal chapters explain the canons; they are the positive formulation of the content of the faith which underlies the condemnation of the errors listed in the canons... It is therefore a safe rule for an interpretation of the decree that it must always start from this delimitating function, that is, from the canons. ${ }^{43}$

On the one hand the Canons displaced the character of donum from the perseverantiae for an ordinary Christian. On the other hand it emphasised the so called character indelebilis which is inerasibly imprinted in the soul by any of the three unrepeatable sacraments of baptism, confirmation or holy order. ${ }^{44}$ That implies that the condition of a baptised person who has apostatised is different to the one who has never been baptised at all. However the actual difference is not specified. Some continuity of grace, though not saving grace, is supposed here.

\footnotetext{
40 Canon 16 in Tanner, Decrees.

41 Canon 16.

42 Stakemeier, Das Konzil, 179.

43 Jedin, History, 2.309.

44 Canons on the Sacraments in General, can. 9.
} 
The first official draft of the Decree on justification from July 1546 had strongly rebuffed any possibility of assurance of one's standing in grace. From August on, however, the question came ever more and more into the centre and became 'die innerkatholische Streitfrage' along with the question of imputed righteousness. ${ }^{45}$ According to Heynck during 15th-26th October from the thirty seven speakers, twenty decided in favour of the possibility of the assurance of grace, fifteen denied it and two did not take a stance. ${ }^{46}$ The clear decision was reached shortly before the closing session on 13th January 1547 that affirmed the final Decree with no exception. ${ }^{47}$ Heynck in his article shows the decisive role of the Franciscan professor Jakobinus Malafossa in arriving at the final decision. He makes an important distinction between two ways of understanding the grace of God: secundum praesentem iustitiam and secundum finalem iustitiam. ${ }^{48}$ In the first case the justification in limited sense is understood (secundum quid), in the second the total justification (simpliciter). This distinction allows him to make the following three statements:

1. According to an ordinary order of salvation no one can know whether he is really in the grace of God 'secundum finalem iustitiam' because any certainty of predestination must be rejected ...

2. According to an ordinary order of salvation, however holy he may be, no one can firmly know whether he lives in the grace of God i.e. whether he shares the justification 'secundum quid' ...

3. Even if according to an ordinary order of salvation one can not know with certainty whether he lives in the grace of God but there may be grounds to assume that he has (at least most likely) obtained his position in grace... 49

Malafossa attempts to answer also the scriptural arguments of his opponents. For the explanation of Romans 8:16 he uses the words of cardinal Cajetano: 'The fact, that we might be children of God, is part of a general confession of faith; that we are really children of God, is a special gift of grace. Such a confession does not enable me to see and know that I am a child of God but only enables me to believe it. ${ }^{50}$

45 V. Heynck, 'Zur Kontroverse über die Gnadengewißheit auf dem Konzil von Trient, Ein bisher unbeachtetes Gutachten des Franziskanerkonventualen Jakobinus Malafossa', in Franziskanische Studien 37 (1955) 1-15, 161-88, 162.

46 Heynck, 'Zur Kontroverse', 162.

47 Stakemeier, Das Konzil, 171.

48 Heynck, 'Zur Kontroverse', 168.

49 Heynck, 'Zur Kontroverse', 169.

50 Heynck, 'Zur Kontroverse', 169-70. 
Little did Malafossa realise that the Council gave an answer to a wrong question. While he was concerned with certitudinaliter cognoscere, the heated argument of the Council was about certitudo fidei-the question whether anybody can be certain with the certainty of faith about his standing in grace. ${ }^{51}$ Certainty of faith stretches beyond simple recognition of one's state. Even his opponents would concede the moral assurance resulting from 'bloß konjekturale Erkenntnis.' The opposition was not against certitudo cognoscere but against certitudo fidei. ${ }^{52}$

The Council of Trent succeeded in eliminating the assurance of believers in their right standing with God in their final state, which was a central issue of the Reformation. Inevitably so since with a little oversimplification one may say that for Tridentine Catholics the emphasis leaned to viewing humans as contributors to their salvation; whereas for Protestants they are receivers which gives them more grounds for certainty. The Reformers' assurance of salvation did not rest on their judgement of their own state of grace but on God's grace itself. Thus W. Pannenberg points to the Catholic O.H. Pesch saying 'that the council rejected precisely what Luther rejected, an assurance of grace in us. In its condemnation, then, the council struck down a misunderstanding and not the real teaching of Luther.' ${ }^{53}$

Later Catholic theologians teach that final perseverance rests on the combination of God's grace and human will. 'Final perseverance is not an object of merit. Rather it is the condition for meriting the attainment of everlasting life. ${ }^{54}$ They uphold the canons of Trent but at the same time assure the believer that he will receive this grace if he assiduously seeks it in true prayer. Every Christian needs special help from God if he is to persevere in justice, which is given to all the just.

While emphasising the need for co-operating grace we can notice another shift upon God's action as it was with Augustine: 'Cooperating grace empowers the human response in both initial conversion and the ongoing living of the Christian life.' ${ }^{55}$ J.J. Connelly

51 Heynck, 'Zur Kontroverse', 173.

52 Heynck, 'Zur Kontroverse', 173.

53 W. Pannenberg, Systematic Theology, 3 vols. (Edinburgh: T \& T Clark, 19931998), 3.163.

54 J.J. Connelly, 'Perseverance, Final' in New Catholic Encyclopedia, vol. 11 (Washington: Catholic University, 1967), 155.

55 M.C. Hilkert, 'Grace, Cooperating', in R.P. McBrien (ed.), Encyclopedia of Catholicism, 583. 
explains that 'every just man receives the grace of potential perseverance. It does not follow that every just man actually perseveres in grace until death. ${ }^{56}$

They speak here about perseverantia passiva and perseverantia activa. Stakemeier explains that children before gaining their reasoning ability, severely mentally handicapped, and adults who die so soon after gaining (or regaining) their justification that they are saved from the struggle for guarding the grace, keep the grace of justification without adding anything of their own. On the other hand all those who have to withstand the struggles and temptations of the Christian life need the perseverantia activa. 'And here we have the blessed juncture when, aided by the merit of the one justified, the hour of death meets the state of grace. ${ }^{57}$ Therefore this grace is inestimable. Even the just man has no way of knowing either his present or his future status before God. Falling away from the faith is an open possibility because it is God who, by His inscrutable providence, coincides man's hour of death at the moment when he is in the faith. In the words of Keating:

For Catholics, salvation depends on the state of the soul at death. Christ has already redeemed us, unlocked the gates of heaven, as it were... He did his part, and now we have to cooperate by doing ours. If we are to pass through those gates, we have to be in the right spiritual state. We have to be spiritually alive. If a soul is merely in a natural state, without sanctifying grace, which is the grace that gives it supernatural life, then it is dead supernaturally and incapable of enjoying heaven. It will not be allowed through the gates. But if it has sanctifying grace, then heaven is guaranteed even if a detour through purgatorial purification is required first. The Church teaches that only souls that are objectively good and objectively pleasing to God merit heaven, and such souls are ones filled with sanctifying grace ... As Catholics see it, anyone can achieve heaven, and anyone can lose it ... Grace abounds and can always be grabbed if only reached for. ${ }^{58}$

Sungenis in his seminal work also believes that Scripture provides conclusive evidence that a believer can finally fall away. ${ }^{59}$ Therefore he has to rely more and more on the means of grace and the church becomes the means of assurance.

56 Connelly, 'Perseverance, Final', 154.

57 Stakemeier, Das Konzil, 178.

58 Quoted by Carson, 'Reflections on Salvation', 604-605.

59 Sungenis, Not By Faith Alone, 298. 


\section{Perseverance Is a Necessary Gift of God and It Is Certain for the Believer}

In accordance with Augustine, Calvin (1509-1564) also based his understanding of final perseverance on the doctrine of election. However, with respect to later developments of Calvinism it is important to note that the starting point for Calvin's discussion, as for Augustine, is the question: Why is it that some people believe and others do not? He answers: 'It comes to pass by God's bidding that salvation is freely offered to some while others are barred from access to it. ${ }^{60}$ The Christian can know about his election only by his being saved and not vice versa.

Without this starting point we might be inclined to understand Calvin as deducing the perseverance of the saints from divine causality which would be completely mistaken. 'In such a causal view the only significant things would be the beginning and the final result of the operation of this first cause while the process by which the final result was reached would be reduced to unimportance. Calvin has no such view.' 61

In variance with the teaching of the Arminians, where God gives in Christ the potential to be saved (salvability), according to Calvin God gives us faith as his seed that brings forth both present and final salvation. Calvin concludes his discussion of objections against assurance by Christ's words: 'Every plant that my heavenly Father has not planted will be pulled up by the roots' [Mt. 15:13]. By these words Calvin believes Christ 'conversely implies that those rooted in God can never be pulled up from salvation' ${ }^{62}$ The false confessor of the visible Church may be uprooted, while the elect of the invisible Church will persevere to the end. Commenting on Jesus' prayer for all the elect [Lk. 22:32] Calvin writes: 'From this we infer that they are out of danger of falling away because the Son of God, asking that their godliness be kept constant, did not suffer a refusal.' ${ }^{63}$ In the visible Church it is humanly impossible to distinguish those who are truly saved from those who are not. In his exposition of Hebrews 6:6 Calvin writes that

60 J. Calvin, Institutes of the Christian Religion, 2 vols. (ed. by J.T. McNeill; Philadelphia: Westminster, 1960), III.XXI.1.

61 G.C. Berkouwer, Faith and Perseverance (Grand Rapids: Eerdmans, 1958), 75.

62 Calvin, Institutes, III.XXIV.6.

63 Calvin, Institutes, III.XXIV.6. 
the Spirit can 'grant the reprobate also some taste of his grace ... There is therefore some knowledge even in the reprobate, which afterwards vanishes away, either because it did not strike roots sufficiently deep, or because it withers, being choked up. ${ }^{64}$ But the assurance of his final perseverance must not lead any Christian to spiritual complacency. 'The faithful promise themselves security in God, and nowhere else; and yet while they do this, they know themselves to be exposed to all the storms of affliction, and patiently submit to them.' ${ }^{65}$ Commenting on Hebrews 12:15 Calvin recognises that it is easy for a Christian to fall away temporarily and therefore: 'We have, in short, need of striving and vigilance, if we would persevere in the grace of God. ${ }^{66}$ This is far from the kind of assurance condemned by the Council of Trent shown above.

The five heads of the Canons of Dort are the Calvinists' answer to the Five Articles which are better known as Remonstrance. The Synod of Dort has marked a final victory of High Calvinism against Remonstrance and within the development of Calvinism. ${ }^{67}$ The first head on Divine Election and Reprobation does not start with an eternal divine decree, but with the state of fallen sinners deserving eternal death. The question of why some people are saved is answered in Article 6:

That some receive the gift of faith from God, and others do not receive it, proceeds from God's eternal decree ... According to which decree He graciously softens the hearts of the elect, however obstinate, and inclines them to believe; while He leaves the non-elect in His just judgement to their own wickedness and obduracy. 68

Article 9 affirms that "this election was not founded upon foreseen faith and the obedience of faith, holiness, or any other good quality or disposition in man, as the prerequisite, cause, or condition of which it depended.' 69 The unconditional character of election is further confirmed in Article 11: "And as God Himself is most wise,

64 J. Calvin, Commentaries on the Hebrews (Grand Rapids: Eerdmans, 1949), 138.

65 J. Calvin, Commentaries of Psalms, vol. 1 (Grand Rapids: Baker Books, 1979), 143.

66 Calvin, Hebrews, 325.

67 For the development of Calvinism see Beeke, Assurance of Faith (New York: Peter Lang, 1994) and especially P. Toon, The Emergence of Hyper-Calvinism in English Nonconformity 1689-1765 (London: The Olive Tree, 1967).

68 Canons of Dort, 1:6.

69 Canons of Dort, 1:9. 
unchangeable, omniscient, and omnipotent, so the election made by Him can neither be interrupted nor changed, recalled, or annulled; neither can the elect be cast away, nor their number diminished. ${ }^{70}$ Here is their teaching of the perseverance grounded.

The Second Head on The Death of Christ, and the Redemption of Men thereby affirms the doctrine of limited atonement. 'The quickening and saving efficacy of the most precious death of His Son should extend to all the elect, for bestowing upon them alone the gift of justifying faith.' ${ }^{71}$ This according to J. Moltmann's observation is 'not Christ offered for all, but Christ as head and effective Lord of the church, the unveiling of God's gracious election. ${ }^{72}$ The distinction of the Persons of Trinity in the process of salvation is important for the Fathers of Dort. The Father elects and the Son saves the elect. 'In that way the work of the Son is placed in the historical centre between the Father's election and the Spirit's sanctification and consummation. ${ }^{73}$

Head $3 \& 4, \S 3$ rejects the teaching 'that the will of itself is able to will and to choose, or not to will and not to choose, all manner of good which may be presented to it.' Their rejection of the free will of man in salvation is reflected also in $\S 8$ and $\S 9$. God not only 'bestows the power or ability to believe', but 'produces both the will to believe and the act of believing also.' 74

The Fifth Head on The Perseverance of the Saints is likely the most complete, balanced and pastorally sensitive creed on the doctrine of perseverance of the saints. It starts on the note of humility stating that God delivers the elect 'from the dominion and slavery of sin, though in this life He does not deliver them altogether from the body of sin and from the infirmities of the flesh. ${ }^{75}$ However, the Fathers of Dort do not use this statement only to call believers to humility but also to substantiate that 'those who are converted could not persevere in that grace if left to their own strength. ${ }^{76}$ King David and the apostle Peter are set as examples of grievous failures. But God even in such cases

70 Canons of Dort, 1:11. The conditional election and perseverance are also explicitly rejected in Head $1, \S 5$.

71 Canons of Dort, 2:8.

72 J. Moltmann, Prädestination und Perseveranz (Neukirchen: Neukirchener Verlag, 1964), 131.

73 Moltmann, Prädestination, 132.

74 Canons of Dort, 3/4:14.

75 Canons of Dort, 5:1.

76 Canons of Dort, 5:3. 
'preserves in them the incorruptible seed of regeneration from perishing or being totally lost; and again, by His Word and Spirit He certainly and effectually renews them to repentance.' 77

Believers may and do obtain a certain measure of assurance of God's preservation. ${ }^{78}$ Canons recognise various degrees of assurance, that come from the Word, "from the testimony of the Holy Spirit, witnessing with our spirit that we are children and heirs of God [Rom. 8:16]; and lastly, from a serious and holy desire to preserve a good conscience and to perform good works.' ${ }^{79}$ Against the Council of Trent the same article stresses that this assurance 'is not produced by any peculiar revelation.'

Because the Synod carefully attempts to keep the canons within the context of the real struggles of believers in this life, it also affirms that

this certainty of perseverance, however, is so far from exciting in believers a spirit of pride, or of rendering them carnally secure, that on the contrary it is the real source of humility, filial reverence, true piety, patience in every tribulation, fervent prayers, constancy in suffering and in confessing the truth, and of solid rejoicing in God; so that the consideration of this benefit should serve as an incentive to the serious and constant practice of gratitude and good works, as appears from the testimonies of Scripture and the examples of the saints. ${ }^{80}$

Thus there is no support of 'Once saved, always saved' regardless of how we live.

The final article ends with a strong and confident note on the doctrine of perseverance: 'Satan abhors it, the world ridicules it, the ignorant and hypocritical abuse it, and the heretics oppose it. But the bride of Christ has always most tenderly loved and constantly defended it as an inestimable treasure. ${ }^{\circ} 1$

Thus the believer's perseverance is grounded in God's election and therefore gives him assurance not only of his present state in grace but also of his final state. This however does not render the present life irrelevant. On the contrary, the believer's faith and general godliness are evidences of his election. If Christ didn't die for all and if having shared in the Holy Spirit ${ }^{82}$ may not be a true regeneration, then a very serious and continuous heart searching follows.

\footnotetext{
77 Canons of Dort, 5:7.

78 Canons of Dort, 5:9.

79 Canons of Dort, 5:10.

80 Canons of Dort, 5:12.

81 Canons of Dort, 5:15.

82 See Heb. 6:4.
} 
One of the most competent interpreters of the Fathers of the Calvinistic churches is the Dutch professor G.C. Berkouwer with the clearest insight into the function of sola fide in salvation. Regarding the doctrine of perseverance he has a penetrating study of the controversy with the Remonstrants, ${ }^{83}$ with Roman Catholics ${ }^{84}$ and Lutherans. ${ }^{85} \mathrm{He}$ looks back to Calvin and observes that 'there is no trace here of speculative conclusions drawn from election or of any notion of merely neutral causality. ${ }^{86}$ It is characteristic for Berkouwer to say that 'one can tread the road of perseverance only in faith, and the doctrine of perseverance is possible only in this faith... Indeed, the doctrine of perseverance finds its only possibility and meaning in the faithfulness of God.' 87

\section{Perseverance Is Necessary but God Does Not Determine Who Will Persevere}

Christians holding this view are usually labelled as Arminians according to Jakobus Arminius (1560-1609). About the perseverance of the saints he said: 'Provided that they stand prepared for the battle, relying on God's help, Christ preserves them from falling so that it is not possible for them to be either seduced or dragged out of Christ's hands by the powers of evil. ${ }^{88}$ Arminius admits that he 'should not readily dare to say that true and saving faith may finally and totally fall away', but he does not exclude such a possibility and notes that some of the Church fathers also seem to affirm it. ${ }^{89}$ In one of his last works 'Arminius protests that he never actually taught that any genuine believer could ultimately apostasize and perish, yet nevertheless concedes that there are passages of Scripture which appear to support such a conclusion... There the matter rests, awaiting further clarification.' 90

\footnotetext{
83 Berkouwer, Faith and Perseverance, 39-45.

84 Berkouwer, Faith and Perseverance, 46-55.

85 Berkouwer, Faith and Perseverance, 55-75.

86 Berkouwer, Faith and Perseverance, 78.

87 Berkouwer, Faith and Perseverance, 79.

88 A.S. Wood, 'The Declaration of Sentiments: The Theological Testament of Arminius', Evangelical Quarterly 65 (1993) 124.

89 J. Arminius, Works of James Arminius, 3 vols. (London: Longman, 1828), 3.454.

90 Wood, 'Declaration', 125.
} 
This has a direct outworking in his teaching on assurance of salvation. He affirms that a believer may have a present assurance of a present salvation. ${ }^{91} \mathrm{He}$ also trusts that believers may leave this life without a terrifying fear with confidence in God's grace. 'Arminius may have been distinguishing between the position of the "believer" and that of the "elect." The "believer" may fall away, but the "elect" could not.' 92

Arminius' understanding of free will is not too far removed from the Roman Catholic understanding of God's grace helping the human will to co-operate with God's grace. He has tried to explain the co-operation of God's grace and human will in the following example: 'A rich man bestows, on a poor and famishing beggar, alms by which he may be able to maintain himself and his family. Does it cease to be a pure gift, because the beggar extends his hand to receive it?' 93 No, it does not cease to be a gift but the salvation is not entirely by grace. Here implicitly the conditional understanding of human salvation is introduced. If the divine grace is given, the human will distinguishes those who accept the gospel from those who reject it and thus the power to be saved is placed in human hands.

This implicit understanding of conditional predestination traced in Arminius was made explicit by his later followers. His successors formalised their creed in Five Articles, better known as the Remonstrance. In the First Article on Conditional Predestination they state that election and condemnation are conditioned by foreknowledge and made dependent on the foreseen faith or unbelief of man. ${ }^{94}$ According to the Second Article on Universal Atonement, Christ's vicarious atonement enabled God 'to enter into a new covenant with men, under which pardon is conveyed to all men on condition of repentance and faith. The immediate effect of Christ's death was not salvation, but only the salvability of sinners by the removal of the legal obstacles, and opening the door for pardon and reconciliation. ${ }^{95}$ The Third Article states that only a man regenerated and renewed by God is able to attain to saving faith. In the Fourth Article on Resistible Grace

91 Arminius, Works, 1.603.

92 Suggestion of C. Bangs and C. Cameron brought forth by D. Bennett, 'How Arminian Was John Wesley?', Evangelical Quarterly 72 (2000) 244.

93 Arminius, Works, 2.52.

94 Schaff, Creeds, 1.517.

95 Schaff, Creeds, 1.518. 
they affirm that 'grace is the beginning, continuation, and end of our spiritual life... But as for the manner of co-operation, this grace is not irresistible, for many resist the Holy Ghost.' 96 The Fifth Article teaches the Uncertainty of Perseverance: 'Although grace is sufficient and abundant to preserve the faithful through all trials and temptations for life everlasting, it has not yet been proved from the Scriptures that grace, once given, can never be lost. ${ }^{\prime 97}$ Thus they have maintained Arminius' ambivalence.

We turn now to the teaching of John Wesley who was more explicit on the possibility of apostasy. Instead of asking Augustine's and Calvin's question: How is it that some people are saved and others are not? Wesley is more concerned with the question: How can a Christian be sure that he or she is saved? His answer can be summarised by the words of Romans 8:16: 'The Spirit himself testifies with our spirit that we are God's children.' In reference to the testimony of our spirit he says: 'You cannot but perceive if you love, rejoice, and delight in God... you must be directly assured if you love your neighbour as yourself. ${ }^{98}$ This is an indirect witness. By displaying the fruits of the Spirit believers can recognise that they are children of God. In the same sermon Wesley defines the testimony of the Spirit as 'an inward impression on the soul whereby the spirit of God directly witnesses to my spirit, that I am a child of God; that Jesus Christ hath loved me, and given Himself for me; and that all my sins are blotted out, and I, even I, am reconciled to God.' 99 This he called the direct witness.

However, later Wesley observed that there were Christians who did bring forth the fruits of the Spirit, 'but to whom there had not been vouchsafed a consciousness of their acceptance with God. In other words, while it was not possible for a Christian to enjoy the direct witness of the Spirit without producing "the fruit", it was possible for a person to exhibit Christian graces and yet be denied an inner sense of spiritual certainty. ${ }^{\prime}{ }^{100}$ But he still maintains that both of these witnesses are common privileges of all believers. ${ }^{101}$

\footnotetext{
96 Schaff, Creeds, 1.518.

97 Schaff, Creeds, 1.519.

98 Quoted from Wesley's sermon by A.S. Yates, The Doctrine of Assurance, With Special Reference to John Wesley (London: Epworth, 1952), 73.

99 Yates, Doctrine of Assurance, 73.

100 Yates, Doctrine of Assurance, 80.

101 Yates, Doctrine of Assurance, 81.
} 
Before moving further with Wesley's thought it is important to clarify the definition of assurance of salvation. He did this in his letter of 28th September 1738 addressed to the Rev. A. Bedford. For Bedford 'assurance of salvation' signifies to persevere in a state of salvation, but for Wesley it means only that we are now in a state of salvation. ${ }^{102}$

Throughout his work Wesley speaks of different degrees of assurance. He particularly distinguishes three:

(1) I believe a few, but very few, Christians have an assurance from God of everlasting salvation. (2) I believe more have such an assurance of being now in the favour of God as excludes all doubt and fear. (3) I believe a consciousness of being in the favour of God is the common privilege of Christians fearing God and working righteousness. ${ }^{103}$

He calls the highest degree 'the full assurance of hope' which is Paul's

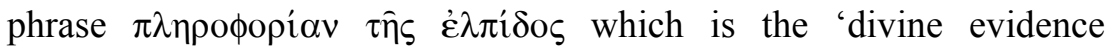
wrought in the soul by the Spirit of persevering grace, and of eternal glory. ...such clear confidence that I shall enjoy the glory of God as excludes all doubt and fear concerning this.' ${ }^{104}$ This leads us to believe that at least Christians attaining this highest degree of assurance can enjoy the certainty of final perseverance. But according to Wesley even that is conditional. "This confidence is totally different from an opinion that "no saint shall fall from grace." It has no relation to it... The giving way to anything unholy... clouds the full assurance of hope: which cannot subsist any longer than the heart cleaves steadfastly to God.' 105

However, here is some inconsistency in Wesley's thought since in his letter to Dr Lavington he writes that the full assurance of hope does imply the full assurance of perseverance. ${ }^{106}$ Thus he admitted 'a state attainable in this life, from which a man cannot finally fall'. ${ }^{107}$ The main interest of Wesley is the second degree which he calls the full assurance of faith ( $\pi \lambda \eta \rho о \phi о \rho i \alpha ~ \pi i \sigma \tau \varepsilon \omega \varsigma)$. It 'is such a clear conviction that $I$ am now in the favour of God as excludes all doubt and fear concerning it.' ${ }^{108}$

\footnotetext{
102 Yates, Doctrine of Assurance, 61.

103 Yates, Doctrine of Assurance, 70.

${ }^{104}$ Yates, Doctrine of Assurance, 130, 131.

105 Yates, Doctrine of Assurance, 131.

106 Yates, Doctrine of Assurance, 130.

107 Wesley quoted in Bennett, 'How Arminian', 239.

108 Yates, Doctrine of Assurance, 131.
} 
Considering the issue of predestination and reprobation Wesley also recognises that an overwhelming sense of assurance may lead a Christian to believe,

that the true grace of God always works irresistibly in every believer! that God will finish wherever he has begun this work, so that it is impossible for any believer to fall from grace! and, lastly, that the reason why God gives this to some only and not to others, is because... he hath absolutely, unconditionally, predestinated them to life, before the foundation of the world! ${ }^{109}$

Having refused the doctrine of unconditional election and examining some relevant New Testament passages, Wesley refuses also the doctrine of limited atonement. ${ }^{110}$ In his sermon On Free Grace he affirms: 'The grace or love of God, whence cometh our salvation, is FREE IN ALL, and FREE FOR ALL.' ${ }^{111}$ The universality of grace is bound with the universality of salvation. A.S. Wood observed that Wesley made a distinction 'between almighty grace and irresistible grace in the matter of salvation. ${ }^{112}$ Grace can do anything consistent with God's character but it can be resisted by the obdurate will of man. Thus even this champion of Christian assurance concludes: 'Whatever assurance God may give to particular souls, I find no general promise in holy writ, "that none who once believes shall finally fall". ${ }^{113} \mathrm{He}$ then goes on to substantiate this conclusion on his exegesis of some twenty-two Old and New Testament passages. In his shorter work Serious Thoughts upon the Perseverance of the Saints based on Romans 8:38-39, Wesley is certain that Paul and many other believers were 'fully persuaded of his own perseverance... But this does not prove that every believer shall persevere, any more than that every believer is thus fully persuaded of his perseverance.' 114

It is clear from this examination of Wesley's writings that his understanding of the nature of perseverance is directly connected with his understanding of the nature of predestination. Final perseverance is the natural consequence of the unconditional decree. Rejecting the doctrine of unconditional election Wesley rejected also its

109 J. Wesley, The Works of John Wesley, 14 vols. (Grand Rapids: Baker, 1984), 10.205 .

110 Wesley, Works, 10.225-27.

111 Wesley, Works, 7.416.

112 A.S. Wood, 'The Contribution of John Wesley to the Theology of Grace', in C.H. Pinnock (ed.), Grace Unlimited (Minneapolis: Bethany Fellowship, 1975), 217.

113 Wesley, Works, 10.242.

114 Wesley, Works, 10.291. 
consequence - the doctrine of final perseverance. As we have noticed already, his assurance is based 'on what is to-day'. It is only a present assurance of the present salvation.

A large proportion of Medieval and modern Catholic scholars have moved away from the Augustinian perception of perseverance as divine gift, to perseverance that is dependent on human effort. ${ }^{115}$ According to Dutch Catholic theologian Scheeben 'we shall only attain the final goal of predestination, heavenly bliss, if we merit it through good works.' 116 The only difference between evangelical Arminians and these Catholics is that for the former final perseverance is a gift of God that is to be maintained and for the latter it is a state which is to be attained - therefore both, gift and merit.

Moltmann characterises the difference between Arminians and Calvinists as follows: 'While God's arms according to Arminians are still open so that everyone can always turn to him, according to Calvinists God's arms have embraced the sinner and do not let him go anymore.' ${ }^{117}$ Because the Arminian must make his election sure by good works, it can lead him to legalism. Because the Calvinist must assure himself of his election by observing the fruits of the Spirit within himself, it can lead him to introspection.

\section{Perseverance Is Necessary for Obtaining Final Rewards but Not for Salvation}

The desire of the Protestant theologians has been so much to prove that salvation by grace alone does not allow moral carelessness and antinomianism of Christians, that the idea of impossibility of losing one's salvation remained largely unconsidered until recently.

Approximately at the same time and in very different parts of the world (one in South Africa and the other in North America) two scholars $^{118}$ have arrived at very similar conclusions on the matter

\footnotetext{
115 For modern representatives see for example Keating and Sungenis, quoted above. A middle ground is adopted by C.R. Meyer, 'Perseverance, Final,' in P.K. Meagler et al., (eds.), Encyclopedic Dictionary of Religion, 3 vols. (Washington: Corpus Publications, 1979), 2739.

116 Quoted in D.G. Bloesch, Essentials of Evangelical Theology, vol.1 (New York: Harper \& Row, 1978), 235.

117 Moltmann, Prädestination, 136.

118 Dillow, Reign; Eaton, Theology of Encouragement.
} 
without making a reference to the other. Their conclusions have not become mainstream in Europe but they are being very effectively disseminated especially in America by the Grace Evangelical Society. They produce a semi-academic Journal of Grace Evangelical Society gathering a wide audience. The main proponent of the view in Britain is R.T. Kendall. ${ }^{119}$ We shall here follow the development of the argument in M. Eaton's Theology of Encouragement.

On the one hand Eaton sets out to reform the scholastic Calvinism because it has led to ever increasing introspection of its believers. On the other hand he accepts the doctrine of universal atonement but sets out to disarm the Arminian legalism. He makes Wesley and Fletcher 'responsible for leading evangelicalism into legalism'. ${ }^{120}$ Thus the Christian who does not pursue holiness has lost his salvation. That is why they speak of conditional perseverance.

Eaton therefore sees a need for a fresh approach to grace. Because 'the relationship between grace and obedience, especially obedience to the Mosaic law, has never been clearly settled', he wishes to present a non-legalistic theology. ${ }^{121}$ That will lead him then to a theology of motivation. However, as much as we may look for A Fresh Approach to Grace in his chapter 5, we find very little explicit treatment of grace in this work at all.

After examining the doctrine of atonement taught in the Gospels, Paul, Hebrews and 2 Peter, Eaton speaks of 'objective and universal atonement' and shows that 'the universal atonement of Christ is one aspect of the ground of Christian assurance of salvation.' 122

In his quest for a non-legalistic theology, Eaton goes into examining the role of the Law in the covenant relationship of believers with God and comes to striking contrasts:

(i) the implementing party (i.e. the one who swears to undertake fulfilment), (ii) personal promise versus national promise, (iii) orientation to crime, public worship, national stability versus orientation to a 'seed' for Abraham, (iv) requirement of faith versus the possible absence of faith, (v) personal renovation versus human ability. ${ }^{123}$

119 R.T. Kendall, Once Saved, Always Saved (Carlisle: Paternoster, 1997).

120 Eaton, Theology, 29.

121 Eaton, Theology, 37.

122 Eaton, Theology, 44.

123 Eaton, Theology, 91. 
Mosaic law must be rejected as inadequate for the Christian. After examining Paul's teaching on the freedom from the Law in Galatians, he comes to a view 'that Paul's statements concerning freedom from, yet fulfilment of, the Torah are consistent. The Christian who walks in the Spirit deliberately fulfils the Torah accidentally. ${ }^{124}$ However, we are not convinced of the need of the Eatonian dichotomy between consciously following God's law and following the Spirit.

This major part of Eaton's work is concluded by an explanation of justification in a non-legalistic theology and particularly by the relationship between justification and sanctification. He wishes to 'modify the traditionally tight link between justification and sanctification'. ${ }^{125}$ If by sanctification we mean progressive growth in holiness, it does not mean that the one who is justified is automatically sanctified also. 'The Christian with an assurance of salvation must consciously and deliberately walk in the Spirit. If he walks in the Spirit deliberately and practises Christian love deliberately he will fulfil the law accidentally. Practical sanctification will have followed justification - but not inexorably.' ${ }^{126}$

Eaton wants to correlate the warning passages of Scripture "with promises and admonitions concerning reward or loss of reward'. ${ }^{127}$ Salvation for a justified Christian is absolutely secure since it depends on Christ only. The present and future spiritual rewards are not yet secure since they depend on the Christian's godly life. As he modified the tight integration of justification and sanctification, he wants to modify also the tight integration of heaven and reward.

In the third part, entitled Motivation, Eaton examines an important biblical concept of 'inheritance' as the reward for a Christian's works of faith. He comes to the conclusion that 'inheritance is not justification. Rather inheritance comes through justification.' ${ }^{128}$ The justification may not be lost whereas 'inheritance may be lost'. ${ }^{129}$

In the final part Eaton deals with admonition in the New Testament and argues that salvation is unconditional. Believers will get to glory. Admonitions are not warnings of loss of salvation but of loss of

\footnotetext{
124 Eaton, Theology, 118.

125 Eaton, Theology, 165.

126 Eaton, Theology, 169.

127 Eaton, Theology, 170.

128 Eaton, Theology, 182

129 Eaton, Theology, 183.
} 
reward. Here we see the great weakness of Eaton's argument. What is that awesome loss of reward? What is the spiritual inheritance that a careless Christian may loose? Eaton accepts that in Hebrews 1:14 'we are introduced to the thought that we are to "inherit" salvation.' 130 It certainly does include reward but salvation itself is what we are to inherit. Examining Hebrews 3:7-4:13 he concludes that 'the loss consisted in God's deciding that they should not inherit what they should have inherited, what they were redeemed for.' ${ }^{131}$ But again, what is at stake if not the eschatological salvation? And what is greater than 'such a great salvation' [Heb. 2:3]?

\section{Summary}

We have examined some plausible arguments in favour of all four historical strands of the Christian doctrine of the perseverance of saints. The positive way forward is not in defusing the tension between divine grace and human responsibility but in maintaining this tension. That can be done by interpreting the doctrine of perseverance not only in forensic but also in relational (covenantal) framework and in better understanding of the doctrine of perseverance within the ordo salutis. ${ }^{132}$

130 Eaton, Theology, 213.

131 Eaton, Theology, 215.

132 I have attempted the latter in J. Henžel, An Evangelical View of the Perseverance of the Believer Within a Revised Order of Salvation (a thesis submitted for the degree of Doctor of Philosophy at Brunel University supervised at London Bible College in December 2000). 